ISSN: $2036-5438$

\title{
Differentiated integration contingent on objective ability: a federalist critique
}

by

\author{
Samo Bardutzky*
}

Perspectives on Federalism, Vol. 10, issue 1, 2018 


\section{Abstract}

This article is inspired by the 2017 discussions on the future of Europe (in particular some of the ideas debated in the White Paper on the Future of Europe, published by the European Commission) and the events that took place in the crises and post-crises period (aftermath of the financial crisis, ongoing refugee crisis and the Brexit shock). It is particularly interested in the scenario of differentiated integration. In this regard, it observes how in the aftermath of the crises, there was a shift in the rationale of differentiated integration with objective (in)ability of the states taking a prominent role. It presents a federalist critique of this development, drawing on the work of Daniel Elazar, discussing the concepts of non-centralization, federal process and federal covenant in the context of the 2017 discussions in the EU.

\section{Key-words}

differentiated integration, crisis, non-centralization, federal covenant, European Union, White Paper on the Future of Europe, weakness, objective inability 


\section{Introduction}

This article observes some of the discussions on the direction that the European Union is going to take after it has lived through some of its recent crises (Eurozone crisis, refugee crisis and Brexit). It focuses on proposals that the Union take the path of differentiated integration: different Member States can deepen their bonds at different intensities. The article also observes that there is a developing trend in the European Union to make the participation of a Member State in the projects of differentiated integration contingent upon the State's objective ability.

This trend is problematic. The main reason is that it threatens to reinforce the centreperiphery divide in the European Union. The article exposes this trend to a federalist critique. The critique is based on the work of Daniel Elazar (in particular his seminal book Exploring Federalism). The starting point of the critique is the central tenet of Elazar's understanding of federalism, the idea of non-centralization, defined in part as the guarantee that the authority to participate in exercising powers will not be taken away from the different sites of power without their consent. When an objective inability of a participant in a federal system threatens to remove from them altogether the chance to participate in the common project(s), this represents an even graver negation of the idea of noncentralization.

The claim in this article is that making participation in projects of differentiated integration contingent upon objective ability would run counter to Elazar's demand for a sense of partnership, that ultimately protects the fundamental integrity of the federal partners. Building on Elazar's description of federalism as capable of reconciling human capacity and human weakness, the claim here is federal process equally demands that partners do not deny each other opportunity to participate based on failure and limited resources.

In its concluding part, the article explores the idea that there is a moral commitment between the partners in the project of European integration that should - on the one hand - serve as an argument for them to maintain the sense of partnership within the federal project. On the other hand, the adherence to this moral commitment should reassure all the partners (including the stronger, abler ones) that the balance between justice and power 
within the federal project will be maintained. In discussing this moral commitment, the article makes use of Elazar's concept of the federal covenant and proposes its own understanding of what Europe's federal covenant ought to be.

\section{2. "Europe at a crossroads"}

Context is of paramount importance to this account; the atmosphere in which these arguments are written is one somewhere between crisis and "post-crisis". Or rather, crises, and "post-crises". First, there is the financial and economic crisis and post-crisis. For the majority of the Eurozone countries, the sovereign debt crisis has ended: Portugal left the economic adjustment programme in 2014, leaving Greece as the only eurozone country still in an adjustment programme. However, in the aftermath of the years of unruly markets and austerity measures, a discussion is now starting on the institutional reform of the eurozone. 2015 and 2016 saw the arrival of a large number of persons (mostly from wartorn Syria, but also Afghanistan and other Asian and African countries) to Europe. The different reactions and rhetoric of the various countries - on the one hand those that were the final destinations of the majority of the arriving refugees, on the other hand those that were predominantly transit countries or that were unaffected by this particular arrival ought to trigger a serious discussion on solidarity, trust, mutual recognition and division of competences in the EU. However, it was the third crisis that served as the most direct trigger for the wider discussion on the future of the EU: the unprecedented decision of a Member State to leave the EU, made by the United Kingdom in 2016-2017. I

It is an atmosphere in which, for the majority of Europeans, there is a tangible presentiment that change is imminent in the European Union, in the way it functions and it is structured. Many Europeans also harbour the emotion that such a change is indeed due at this point in time. Perhaps the most forceful indication of these sentiments was the apprehensive "electoral season" of 2017. Europeans waited, although most of them as spectators, but closely and fearfully, on the results of the presidential elections in Austria and France and the parliamentary election in the Netherlands. Fear that radical right-wing parties, fuelled with the result of the Brexit referendum, calling for more "protection" against foreigners, loosening or breaking ties with the European Union, and reliance on forms of direct democracy, might take over the government in important countries in the 
centre of Europe, leading to a likely break-up of the European union, was real. As was the relief when the populist projects failed for the time being. ${ }^{\text {II }}$

\section{The White Paper on the Future of Europe}

The acknowledgment of the above described sentiments on imminent change, spread widely among the Europeans, that can be considered to have come from the "highest" level as well as in the most formal way is the "White Paper on the Future of Europe", published by the European Commission on 1 March 2017. ${ }^{\mathrm{III}}$ The tone of the introduction to the White Paper is symptomatic of what we have referred to as the atmosphere of crises and post-crises:

... many Europeans consider the Union as either too distant or too interfering in their day-to-day lives. Others question its added-value and ask how Europe improves their standard of living. And for too many, the EU fell short of their expectations as it struggled with its worst financial, economic and social crisis in post-war history. // Europe's challenges show no sign of abating. Our economy is recovering from the global financial crisis but this is still not felt evenly enough. Parts of our neighbourhood are destabilised, resulting in the largest refugee crisis since the Second World War. Terrorist attacks have struck at the heart of our cities. New global powers are emerging as old ones face new realities. And last year, one of our Member States voted to leave the Union (White Paper 2017:6).

The White Paper does not purport to provide definite answers, but rather to present "a range of scenarios for how Europe could evolve by 2025." (White Paper 2017:7). In laying out five scenarios, the document is clear that the idea is not to offer blueprints, but illustrative glimpses into EU's future. Also, the expectation is that the final outcome of the debate in the 27 post-Brexit Member States will be a combination of features from the five scenarios. (White Paper 2017:15). It is quite difficult to speculate in what way the scenarios would be pieced together. Some of them are mutually exclusive and in that sense comparable to different, almost fully opposite directions that simply cannot be taken at the same time. A clear example: what features from Scenarios 2 ("Nothing but the Single Market") and 4 ("Doing Less More Efficiently") could possibly be combined into Scenario 5 ("Doing Much More Together")? ${ }^{\text {IV }}$ 
This is not a claim that the five scenarios of the Commission's White Paper are all mutually exclusive. It is merely a remark that what is on offer in the document is not as wide a selection as claimed in the document itself. ${ }^{\mathrm{V}}$ Many of the directions discussed can be seen as lacking in plausibility or feasibility. ${ }^{\text {VI }}$ What does attract the attention of the observer, however, is the Scenario that would embrace and deepen Europe's penchant for differentiated integration.

\section{4. "Those Who Want More Do More"}

Under Scenario 3, "new groups of Member States agree on specific legal and budgetary arrangements to deepen their cooperation in chosen domains". Adding to such existing arrangements as currency sharing and the Schengen area, examples of potential future "coalitions of the willing" (White Paper 2017:20) as the Commission refers to the smaller groups of Member States, include co-operation in matters of defence or deeper integration in the field of taxation (White Paper 2017:20).

Not only does the Commission's starting point for a discussion include a scenario that envisages a multi-speed Europe, it also seems to be one of the few practically and politically feasible options in the document. Armin Cuyver (2017) is right that the White Paper puts "the ball firmly in the court of the Member States". Many of the Member States in that very court might find it politically more opportune to open the door widely for differentiated integration rather than commit, whole-heartedly, to the "federal scenario", as Avbelj (2017:16) correctly described the "Doing Much More Together" option in Scenario 5.

Differentiated integration may hold considerable appeal to politicians in Member States. But how are we to evaluate the prominence of this solution among the potential paths the Union might go down? In order to do so, an account of the logic/rationale that differentiated integration follows must be developed. The account in this article is based on the established understanding of the rationale of differentiated integration. However, as was mentioned in the beginning of this article, the context in which the proposals for differentiated integration are made, is essential for the understanding of the logic and rationale as well. Hence, the claim made in the continuation is that the rationale has 
changed in the atmosphere of crises and post-crises, and needs to be understood slightly differently than in times of normalcy.

In laying down an established, standard explanation of the rationale, we rely here primarily on the lexicon developed by the political scientists Frank Schimmelfennig and Thomas Winzen (2016:3). Schimmelfennig and Winzen first identify a situation where differentiated integration takes into account efficiency and distributional concerns. They refer to this situation as "institutional differentiation", with its origins in the processes of enlargement of the EU. Given that old member states may be concerned with competition coming from new member states, or, with the ability of newcomers to "meet the policy requirements". However, the objective pursued by institutional differentiation is not only 'protecting' old member states from newcomers, but also extending to new member states "more time to adapt to EU rules and market pressures," for which exceptions are granted. In his account of the different understandings of differentiated integration, built around three ideal types ("multiple speeds", "federal core Europe" and "flexibility à la carte") Daniel Thym (2017:29) similarly speaks of the "multiple speeds" ideal type. Differentiated integration of multiple speeds is where "economic discrepancies", rather than political willingness, guide the distinction between Member States. Thym's (2017:31) concrete example is the creation of the monetary union, which took place gradually, with new members joining once they have fulfilled the convergence criteria.

The other limb of the rationale for differentiated integration is what Schimmelfenning and Winzen (2016:3) refer to as "constitutional differentiation". The motivation that drives "constitutional differentiation", are the "concerns about national sovereignty and identity." Constitutional differentiation is understood by to be "driven by comparatively Euro-sceptic countries that are opposed ideologically, or fear popular resistance, to supranational centralization." Indeed, this second observed motivation seems to closely follow the logic of the Commission in describing the scenario of "those who want more do more". The Commission does not mention the ability or inability of the Member States to participate in a vehicle of differentiated integration. The emphasis - both in the model of constitutional differentiation, and in the Commission's Scenario No. 4, is on the political will of Member States, on their reluctance to relinquish more powers, rather than their capacities.

Differentiated integration based on rationale of the will can of course be seen from two different angles: for unwilling Member States, institutional differentiation is about 
"orientating European integration on national interest" - this is what Thym (2017:34) refers to as "flexibility à la carte". Willing partners, on the other hand, see differentiated integration as a road, albeit a winding one, towards a "finalité fédérale", which is what Thym (2017:32) described as the "federal core Europe" ideal type.

Schimmelfenning and Winzen (2017:4) also contrast the temporary nature of institutional differentiation (e.g. adjustment periods of several years after the accession) with the relatively permanent character of constitutional differentiation. Similarly, Thym (2017:30) recounts how politicians, when arguing for a "multiple speed" approach for monetary union, emphasised that there was no permanent decoupling taking place, but rather that it was only the timescales that were different. The emphasis on the temporary nature of institutional differentiation speaks in favour of our claim that differentiated integration in times of normalcy is only exceptionally motivated on the (in)ability of the (non-)participating Member States.

\section{5. "Those Who (Objectively) Can Do More"}

The situation is different in an atmosphere of crisis. Funda Tekin's 2017 account of differentiated integration purports to contribute to the ongoing discussion of whether it is possible and necessary for all 28 Member States to advance together in the "crisis-ridden EU". Tekin's account already explicitly notes that differentiated integration can not only be about achieving consolidation between the deepening and enlargement of the EU (a goal similar to Schimmelfenning and Winzen's institutional differentiation), but also about the "reversal of integration steps that are already complete", for example Brexit, or the possibility of Greece leaving the Eurozone. Differentiated integration, in 2017,

represents a possibility to compensate for the heterogeneity of the EU member states (MS) in terms of their objective ability and their political will to pool more sovereign rights at the European level. (Tekin 2017:3, emphasis added)

Tekin's example of Greece as a potential candidate for leaving the eurozone is only the most obvious one. All of the Eurozone Member States that have found themselves in need of financial assistance, or even if they were subjected to the different procedures of 
economic co-ordination such as the excessive deficit procedure, felt the threat of "reversal differentiated integration", the threat of finding themselves "thrown out" of the Eurozone on the basis of their objective inability to participate. For these Member States, this was the moment when they grew accustomed to being constantly reviewed, measured and assessed, with the "objective", numerical indicators of economic situation bulldozing through the "subjective" concerns of welfare, equality, social rights and so on (Christodoulidis 2017:64).

The legal dimension of the question of such "reversal differentiated integration", of course, is not to be overlooked. The European Central Bank, in 2009, published a working paper that discussed the possibilities of a withdrawal of a Member State from the euro, but also an expulsion from the euro (Athanassiou 2009). The working paper admitted not only that there are no legal possibilities for the expulsion of a Member State (either from the EU or EMU) but also that the legitimacy of such a solution would be questionable (Athanassiou 2009:35). Yet, the working paper deplored the fact that thereby the Union is deprived of an "ultimate deterrent against a Member State's non-compliance' (Athanassiou 2009:35), and went on to explore indirect avenues of expulsion. Among them, an option that seems to be worth exploring is the use of the mechanism of enhanced co-operation as foreseen by the Lisbon Treaty. But the conditions under which enhanced cooperation can be triggered under the Treaty, such as for example that it should not affect the interests of the countries outside of the club and that it should not compromise the acquis communautaire, were considered excessively strict. The working paper concluded by establishing that, to be able to take the indirect avenue of expulsion, the mechanism of differentiated cooperation would have to be combined with concluding treaties outside of the EU framework. The process would transform the old treaties into empty shells and enable the willing and able to move on to a new club (Athanassiou 2009:36).

The assertion that differentiated integration, in and after the crises, serves to compensate the heterogeneity of the Member States, not only on the basis of their political will, but also on the basis of their objective ability, can be corroborated with help from examples from the other two crises mentioned in the beginning of the presentation: the refugee crisis and even Brexit.

\subsection{Who can manage migration flows?}


The first example must have become visible to anyone who had the opportunity to follow the media and the discourse of national leaders in the countries along the so-called Balkan migration route during and in the aftermath of the 2015 refugee crisis. What seems to have happened during the months when a large number of people travelled along the Balkan route is that the countries on the margin of Europe found themselves in some unsettling type of race in which they wanted to demonstrate that they were capable of using the appropriate jargon - "managing migration flows". ${ }^{\mathrm{II}}$ The impression was that countries such as Slovenia (EU Member State within the Schengen area) and Croatia (Member State, yet outside of Schengen), but also Macedonia and Serbia, countries with a near-quixotic hope of one day joining the EU, were given an opportunity to demonstrate, by adequately receiving, and then either sending on or returning the incoming people, that they are in some way "worthy" of belonging to an area where there are no internal border controls (Greider 2017).

On the Austrian border with Slovenia, Schengen rules have been suspended since 2015, and the suspension has recently been extended for a further 6 months. ${ }^{\text {VIII }}$ Commissioner Avramopoulous declared that this is the final extension that Austria will be granted (Posaner 2018). This was met on the Austrian side with ideas of changing the Schengen rules so that further extensions will become possible. ${ }^{\text {IX }}$ Also, recently, a regulation was adopted tightening security controls at the external borders. ${ }^{\mathrm{x}}$ The application of the regulation in April 2017 led to lengthy congestion on the land border crossings between Slovenia and Croatia (which is an external border of the Schengen area; but an internal border of the European Union). ${ }^{X I}$ Despite the standstill in the country's road traffic, it is my opinion that the fear of the tightening of the controls on the internal borders, de facto pushing Slovenia out of Schengen, was stronger (Cvjetović 2017).

The de facto exclusion from a concrete project of differentiated integration may call for an additional category to be added to the established categorization of differentiated integration, developed by Alexander Stubb (1996). Differentiated integration is categorized in three orders, ranging from least to most legally formal methods of integrating at different speeds. However, it is doubtful that this type of exclusion, based on objective ability of the Member State, i.e. simply prolonging into infinity what was essentially envisaged as an exception, ${ }^{\mathrm{XII}}$ does not seem to fall into any of the categories described by Stubb. If anything, these are "zero order" methods of differentiated integration, posing as 
temporary exceptions, but de facto establishing or modifying projects of differentiated integration.

\subsection{Brexit: traces of a further example?}

Brexit has not yet offered very obvious examples of how the latest of the crises to beset the EU could make differentiated integration contingent, from the perspective of an individual Member State, on its objective ability rather than political will to participate. Splitting the rump EU up, and consequently avoiding having to negotiate with the bloc as a whole rather than individual Member States, may have been how ardent Brexit supporters had envisioned the negotiations. A month before the referendum David Davis, currently the minister in charge of exiting the EU, dreamed of a post-Brexit "UK-German deal [that] would include free access for their cars and industrial goods, in exchange for a deal on everything else..." (Stone 2016). However, by and large, the leaders of EU27 have not even discussed dismantling the current external trade system in the aftermath of the 'Leave' vote in the UK.

But the first, almost knee-jerk response to result from the 23 June referendum was nevertheless a meeting of the foreign ministers of the six founding States of the EU to discuss the referendum decision. The others protested: the four Visegrad Group countries made the reasonable demand that the future of Europe in light of new facts be discussed by all Member States. ${ }^{\text {XII }}$

Ministers meeting, and discussing, does not necessarily construe differentiated integration of any kind; when ministers of the "Founding Six" met earlier in 2016, exactly one year before the $60^{\text {th }}$ anniversary of the Rome Treaty to "discuss setting up a very informal group of "core" countries prepared to push the EU forward" (Palmeri 2016), nobody held their breath. When they met a day or two after the UK electorate decided that for the first time, a Member State was going to leave the Union, the nature of such a meeting was legitimately questioned. Was this the unformal, but de facto "crisis headquarters" of the EU? Or the beginning of the battle for the survival of the fittest fittest in terms of objective ability to deal with the incoming crisis? 
Given that questions on the nature of the crisis meeting of the Six remain unanswered, and that it also seems that the "core" activity of the Six seems to have since subdued, no real analysis can be undertaken to assess whether their initiative was leading towards something more stable and formalized or institutionalized, and whether it would indeed serve as a further example of differentiated integration contingent on objective ability of the "candidate" State.

\section{Differentiated integration contingent on objective ability and the centre-periphery optic in the European Union}

It is nevertheless clear that despite the embryonic form of this new potential project of differentiated integration, the example of the Six reflecting upon Europe's destiny can serve as an example of the increasingly visible divide between the centre and the periphery of the EU.

This divide is not, as one might be quick to conclude, a divide between Brussels as the purported capital of the Union on the one hand and the national capitals on the other hand. The divide, as was particularly persuasively described in the work of Damjan Kukovec (2014), is between economically strong and economically weak Member States. This finding is not affected by the fact that there might be several rich states and rich cities; the centre of the EU may well be in a number of States with the highest GDP per capita.

The centre-periphery divide is not a new phenomenon, and is not solely linked to the crises that the EU has undergone in the past few years. In fact, Kukovec's discussion on the centre-periphery reality of the Union is based on the pre-crisis social rights case law of Viking and Laval, with the divides along the lines of the differences in economic power between the West (by which we mostly mean the "old" Member States of the EU-15) and the East (the post-socialist countries of Central and Eastern Europe that joined in 2004, 2007 and 2013).

After the crisis, the West-East divide was joined by divides set along differences between debtor countries (mostly in the South) and creditor countries (mostly in the North). The centre-periphery optic seems to have strengthened significantly. ${ }^{\mathrm{XIV}}$ The exclusionist, "objective ability" logic, which furnished differentiated integration projects with an air of competition and struggling, seems to be in a relationship of mutual 
strengthening with the deepening centre-periphery cleavages. The atmosphere of competition out of desperation is both a consequence of the widened gap between centre States and periphery States as well as a factor that reinforces the centre-periphery gap.

\section{Differentiated integration contingent on objective ability: a federalist critique}

We draw here on the theory of federalism to present a critique of this possible development. In more precise terms, the federalist critique of the trend of differentiated integration contingent on objective ability relies here on the work of Daniel J. Elazar, and on the view of federalism that he developed in his seminal monograph "Exploring Federalism".

In "Exploring Federalism", Elazar contrasted the centre-periphery model with the matrix model, expressing a clear preference for the latter. The centre-periphery model could not serve as an adequate tool to conceptualize federal systems; but moreover, with a reference to Pierre-Joseph Proudhon, Elazar also discounted it altogether as an appropriate "basis for organizing democratic polities" (Elazar 1987:36). In contrast with the centreperiphery model, there is no single centre in the matrix model, from which all power would flow to the surrounding periphery. Rather, the matrix model consists of a number of centres of power, not centres of higher or lower power, but "larger or smaller arenas of political decision making and action". There are a number of formal and informal lines of authority in the matrix model, which "crisscross" each other: authority may be exercised by local over federal government and vice versa, etc. (Elazar 1987:37). ${ }^{\mathrm{XV}}$

Of course, we must be cautious not to confuse the different functions that these concepts can implement. It is imaginable, of course, although probably not very common, that on a normative level someone would wish for a society, or an organization to be built upon the logic of centre v. periphery. However, the vocabulary of centre-periphery will more often serve as a lens through which to observe, analyse or critique a society or organization. In contrast, the matrix model is much more of a normative ideal. Among the three discussed in his account, it seems to be the one that Elazar advocates, given that it is seen as the prerequisite for functioning federalism. 
In the present account, the concept of centre vs. periphery is applied as a lens through which the reality of the relationships within the EU (between its Member States) is observed. At the same time, on a more normative level, the widening of the gaps between the centre on the one hand and the periphery on the other, is seen as undesirable as it ultimately leads to the creation of second-class Member States and second-class Europeans, and thus to the negation of the values that we consider to be the fundament of the project of European integration: freedom from discrimination on the basis of citizenship.

Elazar's federalism, in this account, serves as a counterpoint. This is based on the normative ideals that Elazar's federalism pursues. These normative ideals, we claim, are reflected in what we understand the goals of the European integration project to be. First, federalism strives to achieve a workable combination of self-rule and shared rule. More precisely, it allows the "peoples and publics" to "do so within the context of limited rule" (Elazar 1987:233). Second, federalism "involves both the creation and maintenance of unity and the diffusion of power in the name of diversity" (Elazar 1987:64). This idea can of course be seen to echo in the Union's official motto, "United in Diversity", described by Schwarz (2016:196) as a "federal maxim".

It should be made clear that way this account uses the word "federalism" is very remote from the common usage of this term in the discussions on Europe. The widespread meaning of "federal" when referring to the EU evokes the visions of a "super-state", of the obliteration of national states and their sovereignty, together with, most likely, cultural and linguistic diversity of the Continent. In the "upper echelons of European politics", writes Stefan Oeter (2006:54), using the "dirty F-word" has been "the equivalent of breaking a taboo". Accordingly, federalism is usually either a flag proudly flown by the most ardent advocates of deeper integration or reserved for the labelling of what are perceived as horror scenarios by adversaries of the federalists.

The reference to the word federalism in the present account, inspired by Elazar's theory, draws upon an idea of federalism that is very remote to the projects of "superstate" either desired or feared by the more radical sides of the discussion on the future of Europe. Crucially, Elazar's federalism encompasses a range of subjects that is much broader than just states. ${ }^{\mathrm{XVI}}$ The emphasis is not on a "particular set of institutions" - it is on the relationships among the participants in political life and the institutional structure that these relationships assume: 
Consequently, federalism is a phenomenon that provides many options for the organization of political authority and power; as long as the proper relations are created, a wide variety of political structures can be developed that are consistent with federal principles. (Elazar 1987:12).

The recognizable similarity of the normative ideals as well as the wide applicability of the theory that does not presuppose a certain form of political organization (i.e. a nation state) speak for the applicability of Elazar's particular vision of federalism to the present discussion.

\section{Critique from Elazar's federalism}

A central concept in Elazar's theory that can be applied in the present account is noncentralization. ${ }^{\mathrm{XVII}}$ In line with Elazar's rejection of a hierarchical and centre-periphery ways of understanding and organizing federal society (as well as democratic polities more broadly) is also the establishment of a stark difference between non-centralization on the one hand and decentralization on the other (see also Burgess 2012:186). A true federal system does not feature the processes of decentralization: the latter is "a matter of grace, not of right". Decentralization is the centre deciding alone whether to relinquish powers to the periphery (Elazar 1987:34).

Non-centralization is a wholly different idea: in a non-centralized system, not only is there a matrix of power (discussed above), ${ }^{\mathrm{XVIII}}$ there is also a constitutional guarantee of a dispersion of power, leading to the power being "so diffused that it cannot be legitimately centralized or concentrated without breaking the structure and spirit of the constitution" (Elazar, 1987:34-35). The different sites of power (national government, governments of the constituent units) can share their powers to a considerable extent, however "the authority to participate in exercising them cannot be taken away from either without their mutual consent" (Elazar, 1987:166).

It can be noted that it seems that in the early nineties, Elazar probably saw the ills of federalism in the European Union in its strong centralism. He criticized the rising popularity of subsidiarity as a potential key tool that would supposedly preserve a balance between the Union and the Member States. He pointed out that subsidiarity was essentially 
and historically an instrument of decentralization, a channel through which the centre can vest powers in the hierarchically inferior (constituent) units (Elazar 1991). ${ }^{\text {XIX }}$

But in 1991, just before the ratification of the Maastricht Treaty, what Elazar saw as the centre, that would then claim the powers for itself, were the institutions of the EU. The centre-periphery gap against which this account claims to caution, is among the states themselves: the core states v. the periphery states. Nowadays the ills of federalism do not seem to lie in the one centre that would amass great powers, relinquished by all (or almost all) of the constituent units. The issue is no longer (to borrow and paraphrase Elazar's words again), whether the authority to participate in the exercise of previously relinquished powers is revoked from the constituent units. No. In a European Union of differentiated integration, contingent upon objective ability, the threat to Elazar's federalist ideal of noncentralization lies in the revocation of the chance to participate in the common project. It may at first only be one element of the common project, or what would be perceived as only part of the integration project. However, it may end up as a revocation of participation from the parts of the project that most adversely affect the population of a Member State, or, indeed, a slow exclusion from the European project altogether.

\section{Federal process and the discussion on the future of Europe}

When a situation presents itself that threatens to reverse or prevent the establishing of a non-centralized democratic polity, can we turn to federalist theory for answers on how to counter the situation? In other words: what might federalism have us do in a situation such as the one we have described in this account?

The reason we can look at federalism as a sort of an overarching structure from the aspect of which a certain development between the Member States of the EU can be observed and critiqued is that there is a constitutive quality to federalism. Federalism is "beyond easy renegotiation", it constitutes a framework within which negotiations and compromises between federal partners take place (Halberstam 2008:143). That is also why it is legitimate for us to ask: what are the deficits of federalism as we live it in Europe today that make possible a development such as the one described in the previous sections?

In searching for the answer, we turn to Elazar and his emphasis on the limits of a structural approach to federalism. The construction of structures that resemble a federal 
system does not, by itself, suffice to shape a democratic policy as a non-centralized one, based on a matrix model. The building of the structures (e.g. a bicameral legislature representing the constituent units in the upper house, institutions of judicial review, etc.) has to be accompanied by 'federal process' if it is to result in the establishment of a true federal polity.

Of course, in 1987, when "Exploring Federalism" was published, this observation by Elazar (1987:68) captured well the quasi-federal systems such as the USSR or the countries in Latin America. To discuss federal structure v. federal process in the European Union of today is a much more complex task: for one, while an imperfect federal structure is in place and available, often the projects of differentiated integration (e.g. Economic and Monetary Union) reside on the margin of these structures.

In addition to that, it is as always impossible to predict whether, in the near future, the structure will only undergo minor changes, radically change or remain intact but eschewed by "those who want and can". What lingers in the air in the present is the not particularly felicitous phrase from the White Paper (2017:15), explaining why it deliberately omits to mention deliberately legal or institutional processes: 'form will follow function'.

Even if the federal structure is not an issue that could be delved deeper into, a discussion on the federal process is highly warranted, if risks to a non-centralized development of the Union in the future are to be averted. In particular, the trend of differentiated integration contingent on objective ability has to be contrasted against the required elements of a federal process, which include

a sense of partnership among the parties to the federal compact, manifested through negotiated cooperation on issues and programs and based on a commitment to open bargaining between all parties to an issue in such a way as to strive for consensus or, failing that, an accommodation that protects the fundamental integrity of all the partners (Elazar 1987:67).

Parallels can be drawn here to the discussion above on non-centralization: the trend of differentiated integration contingent upon objective ability does not put into jeopardy the quest for consensus among the partners but rather an exclusion of some of the partners from consensus-seeking altogether. In case of exclusion of a partner from a project of differentiated integration, not on account of their lacking political interest, but of their 
objective inability, there is no 'accommodation protective of the fundamental integrity of all the partners' that is demanded by Elazar's definition.

But the quest for consensus or protective accommodation of a partner's integration are only manifestations of the essential element of the federal process: a spirit of partnership. Surely, partnership is a broad concept, and it evokes an image of many different relationships between individuals. But on most readings thereof, a situation where a partner would be denied participation in a narrower activity pursued by the corporation or team, based on his inability, would make one doubt the true spirit of such a partnership, not to mention its durability.

\section{0. 'Here I stand, warts and all': federalism and weakness ${ }^{\mathrm{xx}}$}

'All successful federal systems have been rooted in the recognition of man's dual capacity for virtue and vice', writes Elazar (1987:86), 'and have sought to respond accordingly'. In the first place, federalism is tasked with 'harmonizing human capacity and human weakness'. Elazar is referring here to the weakness of human beings to stray from the moral and legal standards of living in a society, abusing their rights or powers and corrupting the system. The control of the different sites of authority over each other (constituent units control the central government, and vice versa, etc.) is to prevent the abuse, the violations, the corruption.

But there is another side to this requirement. Not only are human weaknesses to be kept under control, federal systems must also provide the institutional and legal tools that enable people to exercise their capacity for self-government to the maximum and even grow in that capacity. In a different situation, in Europe in 2017, can federalism not also be tasked with harmonizing capacity (for self-government) and inability (to live up to the certain challenges of the moment)?

In other words: if human weakness in the sense of the 'inherent deficiencies in human nature' (Elazar 1987:86), that lead us to abuse power can be (or indeed has to be) recognized as a necessary evil, with institutions built to manage it and limit it, can the same not be demanded as far as weakness in the sense of failure, inability and limited resources is concerned? 


\section{Justice, power and federal fidelity}

Our critique, and demands for the collective of participants in the European federalist project to accommodate the shortfalls of the weaker and poorer partners, may of course be difficult to accept by the richer and stronger Member States; these might perceive the kind of federalist demands as laid down in this account as disguised requests for additional financial assistance and excessive solidarity. In response, it might be pointed out that Elazar's federalism itself takes "hard realities" into account. In any given federal project, with all the negotiations and bargaining that goes one between the partners and the sites of authority, the content of federalism is not only justice, i.e. the integrity guaranteed to all the partners, the mutual forbearance and self-restraint demanded by Elazar (1987:154). On the contrary: federalism is a combination of the real and the ideal, with the two limiting each other. Federalism cannot only emphasize concern for justice, abandoning concern for power and its relationship to justice. (Elazar 1987:85).

Preventing the more powerful and more objectively able partners from casting aside the weaker partners as they move forward to integration in new fields (or as they consolidate existing projects of differentiated integration) can be interpreted as a limit on their power that they exercise within a constitutional arrangement. This leads us to a decision that needs to be made in the balancing between justice and power as the two elements of every federalism (Moots 2009:395). In searching for the limits that can be set on the exercise of power in the name of justice within a federal system, we can turn to two conceptual explanations. First, the one put forward by Daniel Halberstam and his account of the morality of federal systems; and second a conceptual explanation which draws further on the thought of Daniel Elazar and his idea of covenantal federalism.

Halberstam juxtaposed entitlement-based federalism, on the one hand, and fidelitybased federalism on the other. Under the entitlements approach, all units (constituent and central) are free to use all regulatory instruments that they have at their disposal as per the rules of the constitution: at will, and to further their political interests. It is not that the entitlements approach rejects co-operation between the units and levels; but whether to cooperate is an autonomous decision that one of the units will adopt on its own (Halberstam 2004:732). On the other hand, federalism rooted in "federal fidelity" ("Bundestreue" in the German doctrine) demands that "an institution must temper its political self-interest with a 
general concern for the federal enterprise as a whole". Depending the interpretation of 'general concern', conservative fidelity can be distinguished from liberal fidelity. In the former version of federal fidelity, a unitary view of the general concern is (super-)imposed upon the actors with legal regard for the democratic diversity present within the system (Halberstam 2004:736). In the liberal version, however, actors engage in democratic struggles and conflicts through which the general concern of the federal system is dynamically articulated rather than predefined. However, federal actors' use of regulatory instruments is nevertheless not at their behest: in using them, they pursue the general concern (Halberstam 2004:737).

In his account, Halberstam (2004:735) showed that contrary to commonly accepted perceptions, federalism in the United States is not entirely entitlements-based, nor is German federalism exclusively linked to conservative fidelity, just as the European institutions may not be as devoted to liberal fidelity as is often thought. Federal systems, insofar as the role that general concern for the wellbeing of the entire system plays, converge much more than is usually perceived. Halberstam also put forward a normative claim, relevant to the present account. According to Halberstam (2004:821), liberal fidelity can serve as an appropriate approach to resolving the problems and allocation of power disputes within federal systems where the partners join in a common enterprise of governance.

This can be applied to the problem discussed in the present account as well. Pursuing liberal fidelity would mean acknowledging the reality of existing struggles between competing visions and interests of federal partners. The Member States do see the causes and remedies for the crises discussed differently, and are occasionally tempted to impose their understandings of the situation onto other Member States. However, the limit on any individual unit's power to pursue its vision and interest should be set at decisions that would lead from exclusion or relegation to second-class membership of another Member, despite their willingness to participate and co-operate.

Elazar's account can also help us identify the interpretational guide, that is to be consulted when there are too many possible interpretations of what the spirit of partnership, and the appropriate balance of justice and power, is supposed to be in the federal arrangement of the European Union. This interpretational guide will assist us in clarifying the composition of the requirement that the partners exercise self-restraint and 
mutual forbearance, also when it comes to reacting the objective inability of another partner.

\section{Europe and its federal covenant}

In the interpretation of Elazar's federalism as developed in the present account, this role of such an interpretational guide is fulfilled by a covenant. The idea of a covenant is an important tenet of Elazar's understanding of federalism. In his account, federal polities do not come together by way of force (or conquest), nor do they develop 'organically', by accident. There is a deliberate choice behind the creation of a federal polity (Elazar 1987:3). However, the deliberate choice of the partners to participate in a federal project does not only find its expression in a contract. Clearly, there are contractual arrangements between them, but a contract is, according to Elazar, limited to the legal dimension. There is something more, something deeper, something that endows the agreement to participate with an ethical dimension: a covenant (Moots 2009:394). XXI

In Elazar's thought, there is a further difference between contracts and covenants: contracts are secular. Covenants have a religious dimension or connotation and Elazar (1987:5) traces their history back to the biblical partnership of the people with God. Indeed, God is considered a participant in the agreement that leads to a covenant (Burgess 2012:207). The way the concept of covenant is understood in this discussion, however, does not include its religious dimension. The simple argument, specifically for the context of the European Union, is that the constitutional secularity in many of the Member States would prevent basing a deep-reaching accord between them on a religious foundation. With Elazar himself discussing the possibilities of new postmodernist covenantal arrangements appearing, particularly in the inter-state sphere (Burgess 2012:203), we will permit ourselves to continue and conclude our discussion with what Burgess (2012:207) refers to as a 'modern secular form' of the federal covenant:

Without the Divine spirit it is much more a binding moral commitment between participating individuals, groups, or other entities who voluntarily become partners in creating a new political community. 


\section{Conclusions}

We will posit here that there is in fact a binding moral commitment between the peoples of Europe that have joined to create the European Union. We will reach one last time to Elazar's federalist thought and draw on his insight regarding the constitutions of the constituent units of a federal system, which translated to our discussion are the constitutions of the Member States of the Union. Elazar (1987:174) lamented that they are often neglected and demanded that they are recognized as constitutions 'part and parcel of the total constitutional structure of federal systems'. Constitutions of the Member States thus play a 'vital role in giving the system direction'.

The constitutions of the Member States, as a whole, are a potent expression of the rejection of the horrors of war and totalitarian regimes in XX century Europe. Not all of the constitutions of the Member States were direct consequences of the fall of a totalitarian regime (as were the constitutions adopted in Germany, Italy, Spain, Portugal, countries of Central and Eastern Europe). Other, older constitutions have undergone a transformation on account of the post-war European Convention of Human Rights (Albi 2018). Hence there is a common premise to European Constitutionalism post-WWII and it is a firm 'Never Again' to totalitarianisms, pointless killings and destruction and denial of human dignity.

Agustin Menéndez (2012:72) speaks of the 'deep constitution of Europe', the collective of the national constitutions as well as the common constitutional law of the Member States. The claim in the present account is that this deep constitution of Europe is the common constitutional law of the Member States that is an expression of the values on the basis of which totalitarianisms were rejected and a peaceful Europe, respectful of constitutional democracy, rule of law and of course civil and political rights, was built. This is the binding moral commitment between the peoples of Europe that can serve as the federal covenant of the European Union, informing the interpretation of both the Union's constitution and the 'contract' concluded between the peoples of Europe. It ought to give federal Europe direction, especially at times of crises and post-crises. And to apply this thought to the problem at the beginning of the present account, it should inform the rationale and the criteria of the path of differentiated integration that the Union might take in the future. 


\begin{abstract}
* Assistant Professor of Constitutional Law, University of Ljubljana. The author expresses his gratitude to the conveners and participants of the "Federal Experience of the European Union: Past, Present and Future" conference at the Universidade Nova de Lisboa - Nova Law School (22-23 May 2017), in particular Francisco Pereira Coutinho, José Gomes André, Pieter van Cleynenbreugel, Daniel Thym, Martinho Lucas Pires and Nuno Piçarra. Many thanks also to the anonymous reviewers. All mistakes are author's own.

I Referendum took place on the 23rd June 2016, and the Article 50 notification to the European Council was made on the 29th March 2017.

II Between the moment of writing up the first draft of the article and the moment when it was revised, Sebastian Kurz's People's Party emerged victorious from the Austrian parliamentary elections after an election campaign that focussed on nationalist, migration-averse rhetoric. See Somek (2017) for an analysis.

III European Commission, White Paper on the Future of Europe: Reflections and scenarios for the EU27 by 2025, COM (2017) 202. It ought not be overlooked, also, that later the same month, the "leaders of 27 member states and of the European Council, the European Parliament and the European Commission" issued the "Rome Declaration", pledging to work towards a list of objectives such as "a safe and secure Europe" etc. Indeed, the White Paper understands itself as a prelude to the summit of the leaders (p. 3).

IV More optimistic on the combinability of the scenarios, seeing the latter as "intellectual tools", is Cuyvers (2017).

V In the words of the White Paper (2017:15): “Too often, the discussion on Europe's future has been boiled down to a binary choice between more or less Europe. That approach is misleading and simplistic. The possibilities covered here range from the status quo, to a change of scope and priorities, to a partial or collective leap forward."

VI Matej Avbelj is right, for example, that "Carrying On" is not really an option, and I think there is indeed a wide consensus on that point. The "illusionary viability of the status quo-ante" (Avbelj 2017:9) of the scenarios offering a retracting of the European Union (Scenario 2: "Nothing But the Single Market") is perhaps much more an issue of the political point-of-view of the observer, but it is at the end of the day true that any such operation would be linked to costs and risks of dismantling the existing structures beyond the narrow core of the Union that it would probably not be undertaken.

VII Compare European Commission, Press release: Meeting on the Western Balkans Migration Route: Leaders Agree on 17-point plan of action, Brussels, 25 October 2015, http://europa.eu/rapid/press-release IP-155904 en.htm.

VIII All temporary reintroductions of border controls within the Schengen area are listed on the website of the European Commission https://ec.europa.eu/home-affairs/what-we-do/policies/borders-and-
\end{abstract} visas/schengen/reintroduction-border-control en.

IX The news appears in Austrian media, see for example the article in Der Standard (4 May 2017), available at: http://derstandard.at/2000056966972/Doskozil-will-Grenzen-laenger-kontrollieren-duerfen

x Regulation (EU) 2017/458 of the European Parliament and of the Council of 15 March 2017 amending

Regulation (EU) 2016/399 as regards the reinforcement of checks against relevant databases at external

borders, OJ L 74, 18.3.2017, p. 1-7

XI See the parliamentary question to the Commission posed by Croatian MEP Jakovčić, 9 May 2017 (O000040/2017), http://www.europarl.europa.eu/sides/getDoc.do?type=OQ\&reference=O-2017$000040 \&$ format $=X M L \&$ language $=\mathrm{EN}$.

XII See Agamben (2005), for a discussion of how states of exception (suspensions of juridical order) are becoming permanent arrangements.

XIII See, for example, the article that appeared on the website of Radio Poland ('V4 countries want all EU member states to discuss Brexit') (27 June 2016), available at http://thenews.pl/1/10/Artykul/259050,V4countries-want-all-EU-member-states-to-discuss-Brexit.

XIV Avbelj (2017:3), on post-crisis Europe: “We have witnessed an unprecedented language of the EU's core and the periphery."

XV Elazar (1987:35) also discusses (and rejects) the third, hierarchical/pyramidal model where power relations are organized vertically, with the national/central government are represented as the peak of the pyramid, followed by the lower levels of intermediate and local government.

XVI See a similar point in Burgess (2009:34), or Börzel (2003:2).

XVII Federalism, posits Elazar (1987:64), "is not to be located on the centralization-decentralization continuum but on a different continuum altogether, one that is predicated on non-centralization".

XVIII The many centers among which the power is dispersed are usually to be sought in the constituent 
polities. (Elazar 1987:166)

XIX Daniel Halberstam (2011:13), however, sees "what Europeans call 'subsidiarity"” as the key theoretical concept of a general theory of federalism while at the same time warning of equating federalism and decentralization (Halberstam 2011:12).

xx The phrase 'warts and all', ascribed to Abraham Lincoln, is used by Elazar (1987:86) as a metaphor for human weakness.

XXI The third tool of deliberate partnering is a compact (see for example Elazar 1987:33) with a similar role to play as the covenant, however they 'do not explicitly include a divinely transcendent dimension and instead rely on mutual pledges and a secular legal grounding' (Moots 2009:393). Perhaps the term 'covenant' as we use it here is most correctly placed somewhere between Elazar's covenant and compact.

\section{References}

- $\quad$ Agamben Giorgio, 2005, State of Exception, University of Chicago Press, Chicago.

- Albi Anneli, 2018 (forthcoming), 'Comparative Report', in Albi Anneli and Bardutzky Samo (eds), National Constitutions in European and Global Governance: Democracy, Rights and the Rule of Law, TMC Asser Press, the Hague.

- Athanassiou Phoebus, 2009, 'Withdrawal and Expulsion from the EU and EMU: Some Reflections', ECB Legal Working Paper No. 10, available at: https://papers.ssrn.com/sol3/papers.cfm?abstract id=1517760

- Avbelj Matej, 2017, 'What Future for the European Union?', WZB Discussion Paper SP IV 2017-802, available at: $\underline{\text { https: //ssrn.com/abstract }=3009672}$.

- Börzel Tanja, 2003, 'What Can Federalism Teach Us About the European Union? The German Experience', Paper prepared for the Conference "Governing together in the New Europe", Robinson College, Cambridge, 12-13 April 2003, available at: https://www.chathamhouse.org/sites/files/chathamhouse/public/Research/Europe/borzel.pdf.

- $\quad$ Burgess Michael, 2009, 'Federalism' in Wiener Antje and Diez Thomas (eds), European Integration Theory (Second Edition), Oxford University Press, Oxford, 25-44.

- Burgess Michael, 2012, In Search of the Federal Spirit: New Theoretical and Empirical Perspectives in Comparative Federalism, Oxford University Press, Oxford.

- Christodoulidis Emilios, 2017, 'Subjects and Technologies of European Governance: Reflections on suspect crossings', in Bardutzky Samo and Fahey Elaine (eds), Framing the Subjects and Objects of Contemporary EU Law, Edward Elgar, Cheltenham, 64 -71.

- $\quad$ Cuyver Armin, 2017, 'Five Scenarios for Europe - Understanding the EU Commission's White Paper on the Future of Europe', Verfassungsblog, available at: http://verfassungsblog.de/five-scenarios-for-europeunderstanding-the-eu-commissions-white-paper-on-the-future-of-europe/.

- Cvjetović Srdjan, 2017, 'Velika noč, veliki preizkus za novo uredbo o nadzoru schengenske meje', Siol.net, available at: http://siol.net/trendi/potovanja/velika-noc-veliki-preizkus-za-novo-direktivo-onadzoru-schengenske-meje-439410.

- $\quad$ Elazar Daniel, 1987, Exploring Federalism, University of Alabama Press, Tuscaloosa.

- Elazar Daniel, 1991, 'The European Community: Between State Sovereignty and Subsidiarity', available at: http://www.jcpa.org/dje/articles2/eurcomm.htm.

- Greider Alice, 2017, 'Outsourcing Migration Management: The Role of the Western Balkans in the European Refugee Crisis’, available at: http://www.migrationpolicy.org/article/outsourcing-migrationmanagement-western-balkans-europes-refugee-crisis.

- Halberstam Daniel, 2004, 'Of Power and Responsibility: The Political Morality of Federal Systems', Virginia Law Review, XC (3):731-834, available at: http://www.virginialawreview.org/volumes/content/power-and-responsibility-political-morality-federalsystems.

- Halberstam, Daniel, 2008, 'Comparative Federalism and the Role of the Judiciary', in Whittington Keith E., Kelemen R. Daniel and Caldeira Gregory A. (eds), Oxford Handbook of Law and Politics, Oxford University Press, Oxford, 142-164. 
- Halberstam Daniel, 2011, 'Federalism: A Critical Guide', University of Michigan Public Law and Legal Theory Working Paper Series No. 251, available at: https://ssrn.com/abstract=1924939.

- $\quad$ Kukovec Damjan, 2014, 'Law and the Periphery', European Law Journal, XXI (3): 406-428.

- Menéndez Agustín José, 2012, 'A proportionate constitution? Economic freedoms, substantive constitutional choices and dérapages in European Union law' in Chiti Edoardo, Menéndez Agustín José and Teixeira Pedro Gustavo (eds), The European Rescue of the European Union?: The existential crisis of the European political project, ARENA Report No 3/12 RECON Report No 19, available at: https://pure.au.dk/ws/files/69770796/RECONreport1912.pdf.

- Moots Glenn C., 2013, 'The Covenant Tradition of Federalism: The Pioneering Studies of Daniel J. Elazar', in Ward Ann (ed), The Ashgate Research Companion to Federalism, Routledge, Abingdon, 391-412.

- Oeter Stefan, 2006, 'Federalism and Democracy', in von Bogdandy Armin and Bast Jürgen (eds), Principles of European Constitutional Law, Hart Publishing, Oxford, 53-93.

- $\quad$ Palmeri Tara, 2016, 'Ministers of 'core' Europe plan EU's future: Foreign ministers from founding EU nations to hold talks in Rome', Politico.eu, available at: http://www.politico.eu/article/ministers-core-europeplan-eu-future-rome-meeting-founding-members-integration/.

- Posaner Joshua, 2017, 'Commission extends Schengen border checks for a final time', Politico.eu, available at: http://www.politico.eu/article/commission-extends-schengen-border-checks-for-a-final-time/.

- Schimmelpfenig Frank and Winzen Thomas, 2015, 'Patterns of differentiated integration in the European Union', available at: https://www.ethz.ch/content/dam/ethz/special-interest/gess/cis/europeanpolitics-

dam/documents/People/Publications/Schimmelfennig Winzen differentiated integration revised.pdf.

- $\quad$ Schwarz Michael, 2016, Grundlinien der Anerkennung im Raum der Freiheit, Sicherbeit und Justiz, Mohr Siebeck, Tübingen.

- $\quad$ Somek Alexander, 2017, 'Ex Oriente Lux?', Verfassungsblog, available at: http://verfassungsblog.de/exoriente-lux/.

- $\quad$ Stone Jon, 2016, 'Minister for Brexit David Davis appeared unaware of how EU trade deals actually work', Independent, available at: http://www.independent.co.uk/news/uk/politics/minister-for-brexit-davisdavis-eu-european-union-germany-single-market-trade-deals-unaware-mistake-a 7136121.html.

- Stubb Alexander, 1996, 'A Categorization of Differentiated Integration', Journal of Common Market Studies, XXXIV(2): 283-295.

- Tekin Funda, 2017, 'Differentiated Integration', IEP Online Paper, Institut für Europäische Politik, available at: http://iep-berlin.de/wp-content/uploads/2017/03/Funda-Tekin-Differentiated-IntegrationOnline-Paper2017.pdf.

- Thym Daniel, 2017, 'Competing models for understanding differentiated integration' in De Witte Bruno, Ott Andrea and Vos Ellen Vos (eds) Between Flexibility and Disintegration: The Trajectory of Differentiation in EU Law, Edward Elgar, Cheltenham, 28-75. 